\title{
Introduction: Gender, Rights and Religion at the Crossroads
}

\author{
Mariz Tadros*
}

\begin{abstract}
The introduction to this IDS Bulletin captures why this is the moment for re-engaging with the politics of gender and religion in a securitised post-9/11 context in which 'Muslim communities' have emerged as a political category in their own right. The article traces and exposes how religion has been deployed by international actors, donors, states, feminists, development practitioners, and human rights activists in engaging with gender issues. It analyses both the underlying motives for promoting a 'religionised' form of engagement with gender issues by these actors and how it is reflected in their policy and practice. It argues that various forms of instrumentalisation of religion, gender and human rights need to be examined against the backdrop of volatile political context, the rise of identity politics and increased economic inequality and deprivation. In particular, the article questions what an instrumentalised approach to religion means for negotiating the terms of engagement for addressing women's rights as well as how it impacts their day to day realities.
\end{abstract}

We are at a critical conjuncture in our engagement with issues of religion, politics and women's equality - in particular in relation to the so-called 'Muslim world'. This is because of a number of intersecting factors: a post-9/11 world in which the international community has adopted a dual approach of fighting terrorism while also promoting a 'religious' approach in its dealings with 'the Muslim community'. Using religion as an entry point to engaging the 'Muslim world' has entailed working with religious leaders and faith-based organisations to advance a progressive religious agenda, supporting women who ground their activism in a religious framework. Religion has also become an important entry point in development policy and practice in the light of the entrenchment of neoliberal policies and the rise of identity politics. Faith-based actors have been brought to centre stage as providers of welfare services, mediators of social change and as arbitrators in administering justice. Some Western donors have also espoused an agenda of engaging with Muslim leaders while adopting a religious framework for advancing human rights in 'Muslim communities'. Islamic political and social forces have simultaneously contributed to a process of the Islamisation of society from below. This IDS Bulletin questions what the intersection of global, local and national politics means for policy and practice in the realm of religion and gender.

The articles in this issue explore how religion has been used in an instrumental manner by global, local and national actors as a means of engaging with gender issues in Muslim communities. The deployment of religion is intended to achieve two gains: first, to advance a 'progressive' religious discourse in communities where religion plays an important role in people's lives, and second, to adopt what is considered a more culturally sensitive and 'authentic' approach to eliciting social reform. International actors have deployed human rights to advance security agendas, while many donors have assumed religion as an entry point to elicit social change. States have instrumentalised both religion and secularism to deal with their political opponents. Feminists, human rights activists and development practitioners have sought to form alliances with progressive clerics and mobilise religious idioms, symbols, framings and discourses to accommodate an all pervasive religiosity in the society in which they work. However, the various forms of instrumentalism flagged here need to be set against the backdrop of other contending discourses, which are deeply

IDS Bulletin Volume 42 Number 1 January 2011 @ 2011 The Author. IDS Bulletin (? 2011 Institute of Development Studies Published by Blackwell Publishing Ltd, 9600 Garsington Road, Oxford OX4 2DQ, UK and 350 Main Street, Malden, MA 02148, USA 
entangled in these political debates. These include the use of women's rights discourses by Western governments to justify war (as with Afghanistan) and the deployment of human rights discourses by Islamist groups to legitimise gender inequalities.

This issue of the IDS Bulletin brings together scholars, scholar-activists and development practitioners to share their analyses of the critical challenges and opportunities that are transforming their realities today. A workshop convened at the Institute of Development Studies (IDS) in September 2010 took the debates further, leading to a series of interventions, shared in this issue of the IDS Bulletin. The country experiences shared here include India (Nida Kirmani), Palestine (Islah Jad), Turkey and Afghanistan (Deniz Kandiyoti), Iran (Ziba Mir-Hosseini), UK (Pragna Patel) and Egypt (Hania Sholkamy, Margot Badran, Mariz Tadros and Yousry Moustafa).

The authors problematise a number of overlapping tensions: international actors including donors who have engaged with gender, human rights and religion through the prism of a security agenda. States have presented themselves as the bastions for defending secularism against Islamism, while simultaneously presenting themselves as the protectors of religion and cultural authenticity. Feminists, social movements and human rights activists have found themselves forced to reconsider their strategies of engagement as the normative framework in which they work has become increasingly delineated by religion. Moreover, many activists have found that battles need to be fought over several fronts: on the one hand, they have had to challenge the way in which international human rights frameworks have been applied with double standards, while on the other, fight for the right at home to work within multiple frameworks without having to restrict themselves to the religious normative one.

\section{International donors, women and religion: the conundrums}

Women and gender relations in Muslim societies have always been a site of highly contested political struggles, since the time of colonialism (Said 1978). Yet as Abu-Lughod (2010: 32) reminds us, 'the new twists and turns in global politics have also brought new forms of intersection with gender representing one of the most sensationalised issues on the current global stage, entangled with military intervention and transnational feminism, progressive foundations and right-wing think tanks, elite careers and welfare administration, literary commerce and marginal lives'. For example, the debate between liberal feminists who condoned military action in Afghanistan on account of its violations of women's rights and the radical feminists who condemned it as a form of 'cultural imperialism' served only to essentialise Afghan women further (Kandiyoti, this IDS Bulletin). In this context, a Western gender agenda was deployed to service the security agenda with little impact on shifting conditions on the ground. Kandiyoti postulates that:

The workings of global governance institutions (United Nations agencies in particular) in the service of a gender equality agenda in Afghanistan instituted a form of donor-driven gender activism that could not reach beyond the ministries in Kabul in a country where the writ of the government barely extended outside the capital. This made the technocratic formula of 'gender mainstreaming' politically hollow and ushered in another layer of instrumentalism - this time in the service of development and postconflict reconstruction.

The post-9/11 context was characterised by a two-pronged approach: fighting terrorism through security, and targeting 'Muslims' and 'Muslim communities' through sociocultural interventions. Muslims, a group differentiated by geography, language, cultural, political and historical diversity was homogenised into the 'Muslim community', which had to be 'engaged with' in order to promote human rights values expressed in indigenous - read religious - terms (see Balchin, this IDS Bulletin). Moustafa (this IDS Bulletin) notes that when President Obama visited Egypt in 2009, there was a firm focus on his advisor, Ms Dalia Megahed (a veiled woman), who accompanied him on this visit:

This was a symbolic gesture: engaging a veiled woman is commonly associated with crosscultural interaction. Images of veiled girls are widely used in promotional materials circulated at conferences and other activities sponsored and supported by the international community to communicate with the Muslim 
'world'. The process aims to illustrate the positive presence of Islamic communities in the international sphere, or positive outreach by the international community to local realities.

Donors' annual reports and studies on development aid now celebrate the image of the veiled woman engaging in sports and education, as culturally specific manifestations of liberation expressed in a religious idiom. And it is not just the donors and international organisations that have joined the cause. An Egyptian feminist told the following anecdote: ${ }^{1}$ she was sent to the USA as part of a delegation of young activists where she was asked by the US organisers to make an intervention. She offered to talk about the status of women in Egypt. The organisers decided against it and instead chose another young delegate, a veiled woman, to talk on the topic, even though this was not remotely her area of work or expertise. The justification was that the veiled woman looked more 'authentic' and 'less westernised'.

Moustafa observes that there has been a conspicuous shift in some donor priorities vis-àvis who and what to fund in the Middle East. $\mathrm{He}$ notes that, while in the 1990s funding advocacy for the realisation of political and civil rights was in vogue; today, the focus has shifted towards supporting cultural and religious initiatives. Applications from grantees wanting to make a good pitch for donor funding are increasingly incorporating the participation of clergymen in their funding proposals as partners and stakeholders. 'The message is clear: sociopolitical reform can only be furthered through negotiating the religio-cultural ... The ability of these kinds of projects to integrate clergymen has become an indicator of their success', suggests Moustafa. Sholkamy (2010) argues that the fact that some donors have approached religious engagement as an end in itself, is cause for concern: it means that the goal (gender justice) has been sacrificed as the focus is on the religious pathway itself.

Donor communities' engagement with citizens in terms of their religious identities has had grave consequences: other dimensions of identity (political orientation, ethnicity, language, class) are muted. Yet, as Balchin notes, the engagement with citizens as if they only have one identity, the religious, is congruent with the vision of radical Islamist groups, who have also flagged religious identity as the identifier of a Muslim Ummah - a global nation encompassing all Muslims. Balchin notes that approaches that privilege religion as the developmental issue are in tune with the Islamists' assertion that Islam and Muslims deserve 'special treatment'. Yet, engaging through religious clergymen for example, means that by default, gender hierarchies privileging some actors' positions and roles are espoused. In the Philippines, notes Balchin, local women activists were sidelined and their reproductive health initiatives undermined when donors invited local clergymen to take part in the reproductive health initiative and gave them central roles even in areas where they were not the main decisionmakers. This led to the marginalisation of women activists and the mobilisation of religious forces to create counter-coalitions against their reproductive health initiative.

\section{States mobilising religion, human rights and women}

States have played a crucial role in mediating the international agenda of combating terrorism and 'engaging Muslim communities' in their national contexts. Patel's article shows how, against a backdrop of 'the war on terror', the British government has pursued a series of domestic policies aimed at accommodating religious identity within public institutions. She argues that the shift from a multicultural policy (as problematic as it was) to a multi-faith policy has only encouraged increasing communalisation of South Asian populations in London. The implications are an erosion of secular spaces, spaces in which women who choose not to engage, identify or interact on the basis of religious identity, are marginalised. Institutionally, Patel's own organisation, the Southall Black Sisters (SBS), which serves as a platform for engaging minority women, was sidelined by the local council. The adoption of a faith-based approach to engage with minorities has become a political resource used by the state and the religious right in all communities leading in the same direction: a de-secularisation process.

Yet another set of policies, not incongruent with the above, have also relied on partnering with religious authorities with severe consequences on protecting women's rights. The Muslim Arbitration Tribunal (MAT) in the UK was set up 
and managed in accordance with the Arbitration Act 1996, for alternative dispute resolution in civil law cases, especially family cases in England. Patel argues, in her article, that MAT is an example of how it has widened the power base and authority of patriarchal religious actors whose verdicts have often discriminated against women. Balchin too shows how a neoliberal privatisation agenda stands to gain from relying on the extra-judicial arbitration of family matters under Alternative Dispute Resolution (ADR) legislation. It serves to reduce the case load burden on the formal legal system, leaving it for more 'serious' matters such as commercial disputes. Balchin observes in her article, 'The way a great many ADR systems have worked to date may well be more in tune with hegemonic local cultural and religious norms than the formal legal system, but they have far less often been in tune with the poor's aspirations for justice and women's aspirations for equality.'

The Palestinian National Authority, notes Jad, in this IDS Bulletin, has always infused its nationalist project with Islam but now in its political struggle with Hamas, is deploying religion in a more selective manner, suddenly presenting itself as a defender of secularism in a bid to thwart the Islamist movement.

\section{The uses and abuses of religion and gender: local perspectives}

The case studies from India, Egypt and the UK all point to the way that, faced with contexts in which religion is playing an increasingly prominent role in the lives of citizens or through local and national political dynamics, activists are increasingly adapting religion instrumentally in order to advance their agendas. Kirmani reflects on how the experiences of the Muslim Women's Rights Network (Muslim identitybased) and the Bharatiya Muslim Mahila Andolan (a secular organisation) attempt to work with the highly conservative but influential non-governmental organisation, the All India Muslim Personal Law Board to produce a more woman-friendly contract, produced mixed results. On the one hand, these networks were successful in questioning the authority of religious institutions and showing the many possible interpretations of Islam. Through their campaigning efforts, the networks have widened the space for debate about the relationship between Islam and women's rights and have challenged the image of Muslim women as passive victims. On the other hand, the goal of encouraging women and men to use an alternative religious contract has ultimately failed, except in a handful of cases. Kirmani suggests this is because, although the new contract conformed to religious precepts, this was not enough to elicit social transformation. 'The fact that women are themselves hesitant to claim their rights even if they are convinced that [they are] sanctioned within Islam speaks to the wider patriarchal structures that continue to exist in Indian society, which religious concepts alone cannot dismantle', suggests Kirmani.

Sholkamy engages with the increasing use of religious discourses and actors by social movement activists, development practitioners and donors in Egypt in order to advance their social justice agendas. She finds this a disturbing phenomenon because, 'The promotion of religion as a route to social justice may in the short-term succeed but in the long-term will make religion the arbitrator of politics and of social change'. The first reason why this trend is disturbing is its backlash potential. The use of religious texts to substantiate women's rights and freedoms may seem as a way to speak to the increased religiosity of people living in many contemporary societies but, argues Sholkamy, for every progressive narrative, there is a counter-narrative, which although highly reactionary, bears much resonance in the community. She suggests:

Religious texts are used to substantiate women's rights and freedoms. Female genital mutilation, birth control, sexual rights and rights to property and mobility, we are often reminded, are addressed by Islamic codes that favour women. Unfortunately, satellite channels, popular books and even some textbooks used in seminaries are not in accordance with this progressive interpretation. They are spreading a very different rendition of religious teachings.

The second worrisome issue to emerge is that this form of engaging through conformity to the religious normative framework may only serve to send out the message that only the religiouslysanctioned is feasible and possible. All else based on independent reason, that cannot be religiously sanctioned, has no space or voice, she concludes. 
Moreover, as Patel points out in her article, $£ 45$ million was made available by the British government for 2008-11 to local authorities to tackle extremism among Muslims. In response, Ealing Council's Preventing Violent Extremism fund was set up to engage only Muslims. In view of this new direction of funding faith-based groups, previously secular, black and minority

organisations refashioned themselves as Muslim groups. Some faith-based organisations who do not have progressive social justice agendas have been strengthened through increased visibility and access to funds. Concurrently, women's multiple identities are being condensed into that of being Muslim, whether they are religious or not.

\section{Islamic feminists, moderate Islamists and situating human rights and women in policy and practice}

Women activists who have sought gender justice through Islam are also at the crossroads. Islamic feminists emerged in the 1990s, as a growing wave of women started studying Islam through a hermeneutics and historical approach. There is a consensus that this is highly desirable in that women need to break into this exclusively male arena (see Kirmani, Badran and Mir-Hosseini in this IDS Bulletin). It holds the potential, as Sholkamy argues, of 'feminising Islam'. A feminist engagement through Islam some would argue, is a political necessity in the light of the rise of political Islam and its claims on being the sole legitimate guardians of Islam. Mir-Hosseini asserts:

'Islamic feminism' - feminism that takes its legitimacy from Islam - was the 'unwanted child' of political Islam; it did not emerge because the Islamists offered an egalitarian vision of gender relations. They did not. Rather, their agenda of 'return to the Shari'a' and their attempt to translate into policy the patriarchal gender notions inherent in classical jurisprudence, provoked women to increase criticism of these notions and spurred greater activism among secular feminists, who were now international and had the legitimacy of human rights on their side. The Islamists' defence of patriarchal rulings as 'God's Law' and as promoting an authentic and 'Islamic' way of life, brought the classical jurisprudential texts out of the closet.

Zainah Anwar, founder of Sisters in Islam in Malaysia and a founding member of the transnational movement, Musawah, has taken a similar stance, arguing that the only option to fight the powers of the conservatives who have a stronghold on making claims to being the guardians of religion is to create countermovements. She notes that Musawah 'would make it their business to challenge the use of religion and culture to undo advances in human rights and women's rights'. Anwar (2009) argues that:

When Islam is used as a source of law and public policy, then all citizens must have the right to speak on the subject, Muslims or nonMuslims, secularists or Islamists. Public law and policy must necessarily be open to public debate, and pass the test of public reason. No one demands that you have a degree in political science or economics or social studies before you can talk about politics, economics or social ills. We are deemed qualified to comment simply because we live these realities. But when it comes to talking about Islamic laws, qualifications suddenly become indispensable. We must hold a degree in Islamic studies, we must be able to speak Arabic. Once you've jumped through these hoops, a new condition is set: the hijab. And when we wear the hijab, their masterstroke is delivered - they say our ideas are against Islam.

However, what is debated here is not the critical role of Islamic feminists in Koranic exegesis but the extent to which they can influence gender policy and practice. Do they have the power to influence through a feminist engagement with jurisprudence? Proponents suggest they do, as is evident in the case of the reform of Moroccan family law and the introduction of a woman's right to $k h u l .{ }^{2}$ Counter-arguments are that it was not the presentation of alternative interpretations that tilted the balance in favour of policy reform, but politics - in both cases, the political will of the powers that be. If the pathway to policy reform is through Koranic exegesis, it follows that the struggles are over contending interpretations of texts. However, the struggle seems to be political - between contending interests on a national and international level. In the reform of the Mudawanna, it was not the discovery of a progressive interpretation to the texts that suddenly earned the proposed family law political buy-in, despite the fact that King Hussein II had consistently made the argument that the proposed reforms are commensurate 
with Islam. According to political activist Nabila Mourad, women activists and progressive factions within the government had been advocating for change for years but the regime feared a backlash from the opposition and hence had waited. The right moment came in 2004 shortly after the Casablanca terrorist bombings of 2003, which had strengthened the government's position vis-àvis the Islamist factions. ${ }^{3}$ In the introduction of the khul' article in the Egyptian Personal Status Procedural Law in 2000, what convinced the majority of MPs from the ruling party in Egypt to vote in its favour was not the government line that it derived from Islam, rather it was the threat of losing their political backing from the ruling party if they dare to vote against the proposed article (Tadros 2010).

Badran acknowledges (in this IDS Bulletin) that Islamic feminist movements have enriched the landscape of women's activism, but she expressed concern with the way in which the agency and framing of Islamic feminists tend to fall short of being inclusive of those who do not espouse a Muslim identity or who do not wish to engage through a religious framework. Concern for the inclusiveness of the two Muslim networks under study in India was also voiced by Kirmani in her article in this issue. In return, MirHosseini suggests that Musawah is indeed open to those who espouse a secular framework of engagement even if led by Muslim women.

What becomes evident from the emerging debates is that it is as much about who is engaging as what they are engaging with. Women activists are very aware that historical trajectories, contexts, identities and their own positionalities play an immense role in their ability to withstand attacks from the opposition, and to hold sufficient credibility in the contexts in which they work, to be of influence.

\section{Beyond the binaries and the polemic}

One of the clear messages that emerged from the IDS workshop and the articles featured here, is that the current scholarly approach to the study of gender and religion is wanting - because it is locked in a binary framework of secularism vs religion, modernity vs tradition and moderates vs extremists. As suggested by Kandiyoti, we need new lenses to engage with the complexities of the politics of gender. New lenses however, need the deconstruction of the old, and greater conceptual clarity over what is meant by the religious and the secular.

The dichotomisation of states, political forces, actors and strategies of engagement as either 'secular' or 'religious' conceals multiple and complex ways in which both intertwine, intersect and overshadow each other.

Jad's analysis in this IDS Bulletin, of the historical emergence of the post-colonial Arab state shows how, despite seeming secular, the nationalist governments often used religion to prop up their legitimacy and secure populist support. She reminds us that whereas in the West, de jure secularism called for the formal separation of the church and the state, the Arab state recognised Islam as the religion of society, but de facto demobilised its political use by thwarting organised Islamic movements. The nationalist ideology espoused - whether Baathist, Nasserite or other regime type - distinguished itself from socialism by drawing on Islam. Hence, the whole discourse of secular Arab states fighting Islamism is highly problematic, given the assumptions about the relationship between the state and religion it conceals.

Patel's article on the politics of the UK government espousing multi-faithism in lieu of multiculturalism exposes the fragility of the idea of an allegedly secular state when policy and practice are being increasingly infused with religion, driven by security agendas.

The dichotomy between a secular feminist and an Islamic/Muslim feminist also needs to be scrutinised in the light of the shifts in strategies of engagement. Secular feminists are increasingly using religious framings, texts and idioms in mediating the meanings of international human rights conventions (such as the Convention on the Elimination of Discrimination against Women) to conservative audiences (Sholkamy, Moustafa, Mir-Hosseini, this IDS Bulletin). Likewise, women activists who belong to Islamist movements are increasingly using human rights discourses to substantiate their claims to gendered delegation of rights (Tadros, this IDS Bulletin).

Moreover, coalitions are also being forged between so-called 'religious' and 'secular' actors united by common political interests. For example, a survey 
undertaken by the Association for Women's Rights in Development (AWID) indicated that in Latin America, one of the top five most significant strategies of engagement for highly conservative religious forces is to establish alliances with the secular right. A displacement in religious activism has resulted in religious leaders and discourses being increasingly paired with civil society organisations, as well as scientific, legal or bioethical justifications in defence of dogmatic religious positions. Within the wide range of these organisations, Human Life International is cited most frequently, as its influence extends to most countries in the region. Women's rights activists noted that what characterised reactionary agency against women's rights was not the religious status of the person 'but rather their attempt to influence public policy in defence of a conservative religious and patriarchal agenda'. This also bears evidence to the limitations of the religious vs secular binary in understanding political dynamics behind agendas advanced.

What the IDS workshop revealed is the lack of conceptual clarity on the meaning of secularism (see Sholkamy and Mir-Hosseini, this IDS Bulletin). What does the separation of the church and the state mean in practice? Kandiyoti defines secular spaces:

as spaces where justifications for pluralism and equality can be based on sources other than religious doctrine (though they do not exclude religion as a possible source). Those wishing to use religious arguments to achieve a more progressive reading of women's rights are de facto members of secular spaces since feminists - of whatever persuasion - have little to gain from a closure of public deliberation.

What the articles in this IDS Bulletin suggest, is that secularism and democracy are often used interchangeably in a way that denies the historical incidence of secular systems denying democracy.

For Appleby ${ }^{5}$ it is the secularism of the West that has become so hegemonic as to be exclusionary. He is critical of 'secular fundamentalists' who are the 'dogmatists who proclaim the creed of secularism, as if they were the sole bearers of truth and righteousness'. According to Appleby, secular fundamentalists are the 'dogmatists who proclaim the creed of secularism, as if they were the sole bearers of truth and righteousness' and who will go to great length to crush any forms of religion in the public sphere. On the other hand, Sholkamy, writing from the perspectives of what is happening in Egypt, suggests that it is the religious that has become hegemonic and that the cause and form of religiosity and its relationship with piety and morality is highly complex. The relationship between the religious, the secular and pluralism also lies at the heart of the debate. Some have argued that in social orders where the religious becomes the hegemonic, what emerges is a form of support for communitarianism (under the premise that this is the religion of the majority and it is what the majority wish) under which those who deviate from the religious normative values, order, or ways are rejected.

The construction of the label 'moderate Islam' and pitting it against a radical/extremist Islam is addressed by many authors in this IDS Bulletin (e.g. Tadros, Mir-Hosseini, Patel). The term moderate Islam was conveniently taken up by the West post-9/11 to create a separate category of Islamists - those movements which reject violence as a means of accession to political power. Moderate Islamists are in essence the 'good Islamists' who are believed to be the force that will lead to the carpet being pulled from underneath the feet of the extremists. Many think tanks in the USA and Europe have pushed for greater engagement with the 'moderate' Islamists. To justify this, their democratic credentials have been widely promoted. Interestingly, this has not involved highlighting their democratic credentials vis-à-vis recognising women's full and equal citizenship - perhaps, as Tadros suggests in this issue, because they do fall short of even the modicum of rights constitutionally guaranteed under existing authoritarian regimes. Moderate in relation to what and to whom is conveniently limited to a comparison with the radical Islamists, as if these were the only two politically viable options.

\section{Towards a new research-policy praxis on gender and religion}

There is a sense of urgency in engaging with the politics of international and local engagements with gender and religion on the ground, not least because the spaces to articulate alternative voices and perspectives is narrowing in the post- 
9/11 context, in particular as those who wish to distance themselves from claims to

Islamophobia. Possible charges of Islamophobia lead to muting or censorship of any critical reflection on the practices of Muslim communities. Like the young feminist mentioned above, whose voice in presenting on gender issues was muted because she was not veiled and therefore did not look authentic enough, so too, there are incidents of denying voices in academia and think tanks on the basis that their critiques belie a sense of cultural sensitivity.

The discussions around critical conjunctures in the politics of women, rights and Islam have revealed the need to move beyond the abstract and the polemic and the importance of undertaking context-specific empirical work. One of the limitations of this IDS Bulletin is that the focus is specifically on the deployment of religious discourses, actors and symbols in relation to engagement in Muslim communities in the Middle East and Asia as opposed to a broader comparative focus. This is partly due to the fact that the workshop held at IDS in September followed on from the debates generated in the first issue of the E-Contestations Journal published by the Pathways of Women's Empowerment Consortium. In that issue of Contestations, Sholkamy presented the problematique of assuming a 'Safe Islam' through which gender reform can be advanced. The article was accompanied by a series of responses, some of which were presented by authors who have contributed to this IDS Bulletin.

The focus on the deployment of religious actors and representations by some policymakers in the West is also partly in recognition of the fact that the security and anti-terrorist agendas following 9/11 have been targeting 'Muslim communities' in particular. However, some of the issues raised here also apply to other contexts and religions. There is in fact a growing body of literature debating the role of the Catholic Church in influencing the gender agenda globally, but also on the local-national levels and its implications for women activist movements. ${ }^{6}$

It is hoped that the debates generated here will inform a future research agenda that takes an empirical approach to the study of gender and religion in policy and practice. A research agenda is already emerging, albeit embryonic, that recognises the importance of studying 'fluid networks of influence at the global, national and local levels and engagement with a multiplicity of international, state and non-state actors' (Kandiyoti, this IDS Bulletin). It recognises the centrality of agency and the critical importance of engaging with actors, interests and practices (see Kandiyoti). It recognises that the study of personal trajectories of actors engaged in religious-political-intellectual dialectics is very important (see Mir-Hosseini).

In the meantime, there are a series of critical policy messages emerging from the case studies in this IDS Bulletin that inform both analytical approaches as well as practice.

On an analytical level, the binaries of religious vs secular, moderate Islamist vs radical Islamist, feminist vs Muslim activist, should be suspended. Such binaries conceal the ambiguities and fluidity of identities, strategies of engagement and framing of ideas. This is not to suggest that ideological projects are not important, only that the way in which actors exercise their agency vis$\grave{a}$-vis different audiences and contexts does not fit so neatly into one of two binaries, as problematised by the various case studies presented here.

In terms of policy frameworks, the discourse, and the politics behind 'engaging the Muslim world' as if it were a homogenous category united by religion, should be abandoned. Such a discourse is highly essentialist and engages with men and women assuming they only have one identity marker - their religion. It also feeds into the political agenda of the Islamists who insist that all Muslims should be engaged with exclusively as members in the Muslim Ummah.

On a praxis level, using religion as an entry point in development should be recognised as one of a series of possible approaches to community engagement, and certainly not the only one, even in communities where religion is an important mobilising force. This is not to suggest that religion should be ignored, only that people can be engaged with in various capacities and multiple identities (and not just their religious one). Engagement through the religious framework is one pathway to engaging with gender issues, but it is not ultimately the goal, which is gender justice. 
Finally, a feminist engagement with sacred texts, which involves exposing patriarchal underpinnings that inform dominant interpretations and approaches should be promoted as an end in itself. The benefits are undoubtedly the production of a religious scholarship that is more gender sensitive. However, caution is needed in assuming that a

\section{Notes}

* I would like to thank Professor Deniz Kandiyoti for her thorough and helpful review of this introduction.

1 Interview by the author with Mozn Hassan, Director of Nazra for Feminist Studies, Cairo, July 2010.

2 Arbitrary divorce in return for foregoing some financial rights.

3 Personal communication with Professor Nabila Mourad, 27 October 2010.

4 Fundamentalist Strategy: The Secular and the Religious, Juan Marco Vaggione, 17 September 2010, www.opendemocracy.net/juan-marco-

\section{References}

Abu-Lughod, Lila (2010) 'The Active Social Life of "Muslim Women's Rights": a Plea for Ethnography, Not Polemic, with Cases from Egypt and Palestine', Journal of Middle East Women's Studies 6.1: 1-45

Anwar, Zaina (2009) 'Bearers of Change', New York Times, www.nytimes.com/2009/03/05/ opinion/05iht-edanwar. 1.20613399.html? pagewanted $=1 \& \_r=2($ accessed $6 \mathrm{March}$ 2009)

Said, Edward (1978) Orientalism, New York: Vintage feminist re-engagement with religious text within a religious framework is a panacea for altering gender bias in laws, policies and practices. The politics of transforming gender power hierarchies may require strategies that go beyond dismantling the patriarchal religious premises upon which they were justified; and in some cases they may not be, at the core, about gender at all.

vaggione/fundamentalist-strategy-secularand-religious

5 'Of Fundamentalisms, Secular or Otherwise', R. Scott Appleby, 27 September 2010, www.opendemocracy.net/5050/rscottappleby/of-fundamentalisms-secular-andotherwise

6 For a more recent reading of religion and gender on a country level, Shahravi, R. and Jennichen, A. (2010) Third World Quarterly 31.6, offers case studies of the Catholic church's impact on the gender agenda in Mexico, Chile and Poland.

Shahravi, Razavi and Jennichen, Ann (2010) 'The Unhappy Marriage of Religion and Politics: Problems and Pitfalls for Gender Equality', Third World Quarterly 31.6

Sholkamy, Hania (2010) 'Islam and Feminism', Contestations 1, www.contestations.net/issues/ issue-1/religion-and-gender-justice/ (accessed 1 October 2010)

Tadros, Mariz (2010) 'Feminism through Safe Islam?' Contestations 1, www.contestations.net/ issues/issue-1/religion-and-gender-justice/ (accessed 15 June 2010) 